\title{
New insights in flat oyster Ostrea edulis resistance against the parasite Bonamia ostreae
}

\author{
B. Morga, T. Renault, N. Faury, I. Arzul
}

Institut Français de Recherche pour l'Exploitation de la Mer (Ifremer), Laboratoire de Génétique et Pathologie (LGP), Avenue de Mus de Loup, 17390 La Tremblade, France

\author{
*: Corresponding author : Isabelle Arzul, Tel.: +33 5467626 10; fax: +33 546762611 . \\ email address : iarzul@ifremer.fr ; isabelle.arzul@ifremer.fr
}

\begin{abstract}
:
Bonamiosis due to the parasite Bonamia ostreae has been associated with massive mortality in flat oyster stocks in Europe. Control of the disease currently relies on disease management practices and transfer restriction. Previously, massal selections based on survival to challenge to infection with B. ostreae have been applied to produce flat oyster families with resistant progeny. In an attempt to understand the molecular mechanisms involved in disease resistance, differentially expressed sequence tags between resistant and wild Ostrea edulis haemocytes, both infected with the parasite, were identified using suppression subtractive hybridisation. Expression of seven ESTs has been studied using quantitative reverse-transcriptase PCR. The base-line expression of an extracellular superoxide dismutase, inhibitor of apoptosis (OelAP), Fas ligand (OeFas-ligand) and Cathepsin B was significantly increased, whilst cyclophilin B appeared significantly decreased in resistant oysters. Considering their great interest for further studies, the open reading frames of the OeFas-ligand and OelAP were completely sequenced.
\end{abstract}

\section{Graphical abstract}

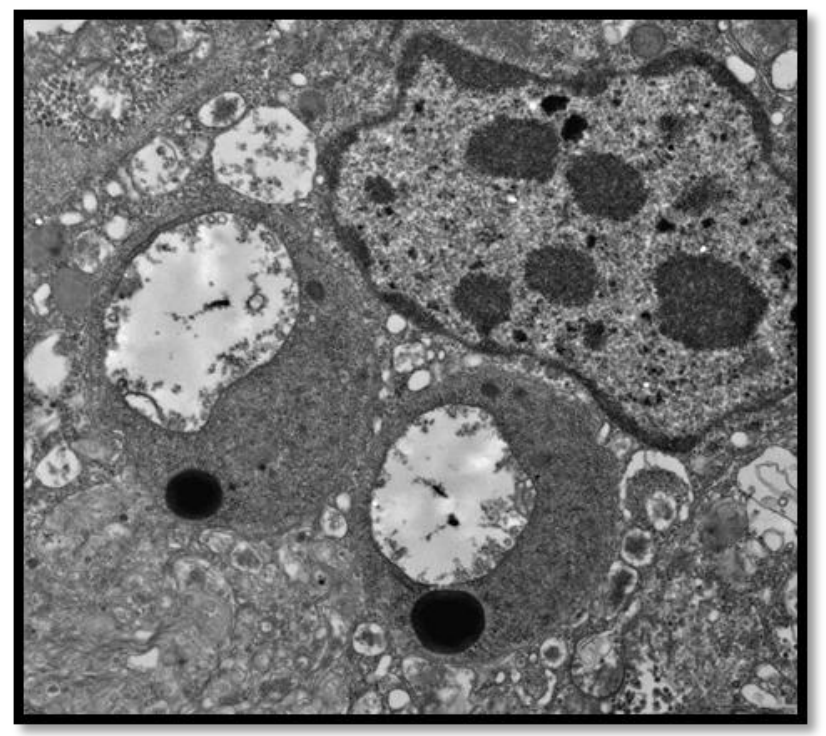




\section{Highlights}

- Bonamia ostreae is an intra-haemocytes parasite. Flat oyster Ostrea edulis, is the natural host of B. ostreae. In this study we have studied genes expressed in response to the parasite. Extracellular superoxide dismutase (OeEcSOD) is up regulated in resistant haemocyte. Genes involved in apoptosis is up regulated in resistant haemocytes from flat oyster

Keywords : Protozoan ; Ostrea edulis ; Flat oyster ; Transcriptomic ; Gene expression 


\section{Introduction}

Oyster farming is currently exposed to heavy mortality associated with the detection of pathogens (virus, bacteria and parasites). Treatment cannot be used because oysters are mainly cultured in open areas and vaccine cannot be developed because molluscs lack lymphocytes and antibodies. Consequently bivalve disease control generally relies on stock management and transfer restriction. Development of resistant animals when possible can also help to mitigate disease impacts.

Bonamia ostreae has contributed to decrease flat oyster Ostrea edulis production in France since the end of the seventies [1] and [2]. This protozoan is affiliated to the order of haplosporidia and to the phylum of cercozoan [3]. $B$. ostreae is most often observed inside the haemocytes [1] and [2], but it can also be observed extracellularly in the digestive gland and in the gills [4]. Haemocytes, the circulating cells present in haemolymph, play a key role in the immune response of molluscs. Bivalves lack specific immune system and immune memory. Their immune response relies on innate cellular and humoral mechanisms both operating in coordination to recognize and eliminate pathogens. Phagocytosis is the main cellular immune response against pathogens in molluscs [5]. Thus, the better comprehension of interactions between the immune system of oysters and pathogens are key factors to understand the development of related diseases.

Selective breeding programs were initiated in Ireland and France, with the main objective of producing flat oysters resistant to bonamiosis [6] and [7]. In France, this program was first initiated in 1985 by Ifremer (Intsitut Français de Recherche pour l'Exploitation de la Mer), producing two oyster populations by mass spawning [8]. Individual selection was applied through inoculation tests and field testing, the surviving oysters being used to produce the next generation. Three generations of selection were produced in Ifremer hatchery. At that stage, microsatellite analyses showed that these strains exhibited low genetic diversity due to population bottlenecks, leading to small effective population sizes and subsequent inbreeding [9]. As a result, the second stage of this selective breeding program consisted of the production of bi-parental families combined with within-family selection. Families produced in 1995 consisted of within-strain crosses. Then, in order to maximize genetic variability, families produced in 1998 were issued from among-strain crosses between two families previously produced. These families showed enhanced survival and lower prevalence of the parasite compared with control wild-type oysters in $B$. ostreae contaminated areas [7].

Such material is also helpful to better understand resistance basis. As an example, in the Sydney rock oyster, Saccostrea glomerrata the use of selected oyster against the parasite Marteilia sydneyi allowed identifying genes involved in the resistance to the disease [10]. In the present study, a comparison of the molecular responses between a resistant population and some wild oysters was undertaken using suppression subtractive hybridization (SSH), a PCR-based technique that allows the identification of genes that are differentially expressed between two conditions. In addition, RT-PCR assays were developed in order to estimate expression level of ESTs of interest during an in vitro infection of haemocytes from resistant and wild oysters. Finally, the open reading frames of two selected genes (OeFas-ligand and OeIAP) were completely sequenced and characterized. 


\section{Material and methods}

\subsection{Biological material}

\subsubsection{Oysters}

Eighteen-month-old flat oysters Ostrea edulis $(n=90)$ were collected from Quiberon Bay (Southern Brittany, France), a bonamiosis endemic zone. They were acclimatized in the quarantine facilities of Ifremer laboratory in La Tremblade (Charente Maritime, France) over 30 days. These oysters are considered as the wild population in this study.

The resistant oysters were produced in the Ifremer hatchery from Argenton (Northern Brittany, France) from spawners previously selected for their resistance to bonamiosis. When they were 18 months old, they were transferred and acclimatized in the quarantine facilities of Ifremer laboratory in La Tremblade (Charente Maritime, France) over 30 days.

Flat oysters were maintained in 120 I raceways supplied with a constant flow of seawater enriched in phytoplankton (Skeletonema costatum, Isochrisis galbana, Chaetoceros gracialis and Tetraselmis succica).

\subsubsection{Haemolymph collection}

Haemolymph was withdrawn from the adductor muscle using a $1 \mathrm{~mL}$ syringe equipped with a needle $(0.40 \times 90 \mathrm{~mm})$. Haemolymph samples were filtered on a $75 \mu \mathrm{m}$ mesh to eliminate debris and $m$ aintained on ice to prevent cell aggregation. Haemolymph samples were pooled. Haemocyte counts were performed using a Malassez-cell and cell concentration was adjusted at $2.10^{6}$ cells $\mathrm{mL}^{-1}$ with filtered seawater at $0.22 \mu \mathrm{m}$ (FSW).

\subsubsection{Parasites}

B. ostreae was purified according to a previously published protocol [11]. Briefly, heavily infected oysters were selected by examination of heart tissue imprints using light microscopy. After homogenization of all the organs except the adductor muscle, the parasites were concentrated by differential centrifugation on sucrose gradients and then purified by isopycnic centrifugation on a Percoll gradient. Finally, the purified parasites were suspended in FSW. B. ostreae cells were then counted using a Malassez-cell and parasite concentration was adjusted at $10.10^{7}$ cells $\mathrm{mL}^{-1}$ with FSW.

\subsection{In vitro infection protocol}

In vitro infection experiment including infected haemocytes from resistant oysters and infected haemocytes from wild oysters was performed in order to construct forward and reverse SSH libraries.

The expression level of some genes identified through SSH was then evaluated through a second in vitro experiment including two conditions i.e. (1) infected haemocytes from resistant oysters and (2) infected haemocytes from wild oysters.

Whatever was the experiment, haemocytes were maintained in contact with purified parasites during $2 \mathrm{~h}$. For that purpose, $5 \mathrm{ml}$ of haemocyte suspension were introduced in plastic cell culture flasks and incubated at $15^{\circ} \mathrm{C}$ for two hours until the formation of a cell layer. Supernatant was then withdrawn, preserved after $0.22 \mu \mathrm{m}$ filtration and replaced by $500 \mu$ of parasite suspension. After 2 hours, supernatant previously filtered at $0.22 \mu \mathrm{m}$ to eliminate bacteria, was introduced again in flasks. After 12-hour incubation, cells were rinsed twice with phosphate buffer saline (PBS 1X) and were processed for RNA extraction using TRIZOL reagent (Invitrogen) following the manufacturer's instructions. 


\subsection{Suppression subtractive hybridisation (SSH)}

One $\mu \mathrm{g}$ of mRNA from the haemocytes exposed to the parasite and $1 \mu \mathrm{g}$ of mRNA from the haemocytes alone were used as templates for the SSH following the PCR-select cDNA subtraction kit procedure (Clontech, Palo Alto, CA) [12]. Forward subtraction was carried out using the haemocytes from resistant oysters exposed to the parasite as the tester and the haemocytes from wild oysters exposed to the parasite as the driver. The opposite was performed for reverse subtraction. PCR products were cloned using TOPO TA Cloning Kit (Invitrogen). White colonies were screened by macro-arrays. Inserts were PCR amplified using TOPO $\mathrm{F}$ and R primers (Table 3 ) and $1 \mu \mathrm{L}$ of PCR products was spotted in duplicate onto nylon membrane (Roche Diagnostic). cDNA was digoxygenin labelled and used as probe in hybridisation experiments using the DIG-labelling and detection kit according to the manufacturer's instructions (Roche Diagnostic).

\subsection{Sequencing and sequence analysis}

Clones showing a differential digoxigenin labelling intensity between tested conditions were selected and amplified using TempliPhi DNA Sequencing Template Amplification Kit (Amersham's). PCR products isolated from individual clones were sequenced in one way with TOPO $F$ with the sequencing kit $A B I$ BigDye ${ }^{\circledR}$ terminator version 3.1 using an $A B I$ PRISM尺 3130 XL-Avant Genetic Analyzer, a $36 \mathrm{~cm}$ capillary array and POP 7 polymer. Chromatograms were analysed with Chromas 231 software. Sequences were then analysed with BlastX algorithm available from the National Center for Biotechnology Information (NCBI). EST sequences were then submitted to dbEST and GenBank databases (http://www.ncbi.nlm.nih.gov/blast/). Only E values less than $10^{-4}$ were considered significant.

\subsection{Identification and characterization of immune-related genes}

In order to obtain the complete open reading frames (ORF) of Fas-ligand (OeFas-ligand) and inhibitor of apoptosis, IAP (OeIAP), RACE PCR reactions were carried out using SMART RACE cDNA Amplification Kit from Clontech according to the manufacturer's instructions. 5' and 3' primers were designed using primer 3 software (http://biotools.umassmed.edu/bioapps/primer3 www.cgi) (5'racefas TGAGTTAGCCCTGTTTCTCCACCAG, 3'racefas CTGGTGGAGAAACAGGGCTAACTCA; 5'racelAP CCTCCATGTCAAAAATCACATTAGC, 3'raceIAP ATGTGATTTTTGACATGGAGGAGAG). After ligation and cloning in TOPO Vector System (Invitrogen) and transformation in Top 10 competent bacteria (Invitrogen), several clones were sequenced using the same protocol as described before. Open reading frames were identified using the ORF finder in NCBI. Complete sequences were deposited in GenBank and assigned under the accession numbers GU320694 (OeFas-ligand) and GU814273 (OelAP). The isoelectric point and molecular mass were calculated in http://www.expasy.ch/tools/pi tool.html.

\subsection{Phylogenic analysis of OeFas-ligand}

The sequence of the complete ORF of OeFas-ligand was aligned with Fas ligand, TNF alpha and lymphotoxin alpha genes from GenBank database.

Alignments were performed using the Clustal W [13] including in MEGA 4 [14]. A phylogenic tree based amino acid sequences was designed using the Neighbour-Joining (NJ) [15] algorithm with the MEGA $4 \mathrm{~s}$ oftware program. Statistical confidence on the inferred phylogenic relationships was assessed by bootstrap of 1000 replicates. 


\subsection{Expression analysis of selected ESTs by quantitative real-time PCR}

Total RNA was extracted using TRIZOL reagent (Invitrogen) following the manufacturer's instructions. First strand cDNA was synthesized using the oligo(dT) anchor primer (5'-GAC CACGCGTATCGATGTCGACT(16)V-3') and Moloney murine leukaemia virus (M-MLV) reverse transcriptase SuperScript III First-Strand Synthesis System for RT-PCR (Invitrogen). For each of the selected genes, forward and reverse primers were designed using primer 3 software (http://biotools.umassmed.edu/bioapps/primer3 www.cgi). Real-time quantitative PCR reactions were duplicated and performed according the previous study presenting in Morga et al., 2010 [17].

For each candidate gene, melting curve and gel picture were analysed in order to verify the specificity of the amplified products and that at a single PCR product was amplified. PCR efficacy (E) was calculated for each primer pair by determining the slopes of standard curves. These curves were generated using a serial dilutions analysis of plasmid containing the insert of interest. Amplification efficacies were calculated according to the following equation $E=10^{(1-\text { slope })}[16]$.

The expression of the candidate genes was normalized using the elongation factor 1 alpha (EU651798) as the housekeeping gene. Primers are shown in Table 1 [17]. Resistant infected haemocytes were used as a control in order to identify the relative expression of selected genes in infected wild haemocyte. Wild infected haemocytes were used as a control in order to identify the relative expression of selected genes in infected resistant haemocyte Fold units were calculated using the method described by [16].

\section{Results}

\subsection{Identification and selection of candidate ESTs}

The SSH technique was used to identify transcripts differentially expressed between infected haemocytes from resistant oysters and infected haemocytes from wild oysters. Two thousands and two hundred eight clones were sequenced and 1920 sequences $(95 \%$ of the sequenced clones) were obtained and analysed (see Table 2). These sequences ranging from approximately 152 to $670 \mathrm{bp}$ in length were analysed for the redundancy by multiple alignments using the Lasergene software. Finally, 909 unique ESTs were identified including 333 contigs and 606 singletons. Among these, 382 ESTs showed similarities with genes available in databases with an $\mathrm{E}$ value $<10-4$ clustering in 8 main categories according to their putative functions predicted by NCBI using GO (Gene Ontology) (Fig. 1); (1) detoxification and stress, (2) cell communication, membrane receptor and immune system, (3) ribosomal protein, (4) cystoskeleton structure, (5) respiratory chain, (6) cell cycle, DNA repair, protein regulation and transcription, (7) cell metabolism and (8) hypothetical proteins. Based on their putative function, seven ESTs have been selected in (1) detoxification, (2) cell communication, membrane receptor and immune system (extracellular superoxide dismutase (OeEcSOD), inhibitor of apoptosis (OeIAP), OeFas-ligand, cathepsin B and cyclophilin, ferritin and $\mathrm{OeC1q}$ ) (Table $3 \mathrm{a}$ and $3 \mathrm{~b}$ ). Extracellular superoxide dismutase (OeEcSOD), inhibitor of apoptosis (OelAP), OeFas-ligand, cathepsin B and ferritin have been selected in forward bank and Oe-C1q and cyclophylin were selected in reverse bank.

\subsection{Characterization of Ostrea edulis immune-related genes}

\subsubsection{Ostrea edulis Fas ligand (OeFas-ligand)}


OeFas-ligand cDNA showed a 1097 nucleotide (nt) sequence. The sequence contained a short 5'-untranslated region (1-29 nt) followed by an ORF of $863 \mathrm{nt}$ (287 codons: 30-893 nt) and finished by a 3'-untranslated region (894-1097 nt) (Fig. 2). The complete ORF product had a putative molecular mass at $32442.70 \mathrm{Da}$ and a predicted isoelectric point at 6.75. The analysis of the ORF product revealed the presence of the transmembrane domain (MIFSCAVNVVLAIVFGVLVGLNW) and a TNF domain (154-257). Moreover, tree Nglycosylation sites at ${ }^{57} \mathrm{NATV}^{60},{ }^{85} \mathrm{NETL}^{88}$ and ${ }^{125} \mathrm{NSSS}^{128}$ could be identified. Signal peptide prediction results showed that there was a putative signal peptide in the OeFas-ligand (MSAPSSRNCKCFMIFSCAVNVVLAIVFGVLVG).

Phylogenic tree analysis of Fas ligand, TNF alpha and lymphotoxin alpha grouped OeFasligand within the Fas ligand clade and showed closest affinity with its homologous in abalone Haliotis discus hannai (Fig. 3).

\subsubsection{Ostrea edulis Inhibitor of Apopotosis (OelAP)}

OelAP cDNA was composed of 1241 nucleotides (nt) in length. The sequence contained a short 5'-untranslated region (1-16 nt) followed by an ORF of 1076 nt (377 codons: 17-1150 nt) and finished by a 3'-untranslated region (1151-1241 nt) (Fig. 4). The complete ORF product showed a molecular mass at $41646.89 \mathrm{Da}$ and predicted isoelectric point at 5.63. ScanProsite analysis revealed that the predicted OeIAP protein contained one BIR domain (93-158 aa), followed by a RING domain (330-365) at its $C$ terminus. Moreover, it was identified one $\mathrm{N}$-glycosylation sequence at ${ }^{51} \mathrm{NETD}{ }^{54}$. The BIR domain of OeIAP had the conserved BIR motif of $\mathrm{CX}_{2} \mathrm{CX}_{6} \mathrm{WX}_{3} \mathrm{DX}_{5} \mathrm{HX}_{6} \mathrm{C}$ [18]. OelAP is more similar to the ML-IAP (livin), a human IAP that contains a single BIR and RING finger domain than to IAP identified in invertebrates. The multiple alignment of BIR domains from Penaeus monodon IAP (PmIAP ABO38431.1), Drosophila melanogaster (DIAP1 Q24306.2) and (DIAP2 AAF58095.1) and Homo sapiens sapiens ML-IAP (Iivin NP_647478.1) showed a maximum of $62 \%$ identity with the BIR3 from PmIAP (Fig. 5). The multiple alignment of RING domain between Oe-IAP RING domain and the DIAP1, DIAP2, PmIAP and livin RING domain showed $61 \%$ of identity with livin RING domain (Fig. 5).

\subsection{Haemocyte expression of selected ESTs}

In order to verify that differential expression of genes identified by $\mathrm{SSH}$ existed between resitant and wild oysters, GRT-PCR was carried out to determine the relative expression of the target genes. SSH libraries allowed identifying seven ESTs potentially involved in the resistance or susceptibility to bonamiosis. Significant differences in expression were observed between resistant and wild oysters for five of the seven transcripts. OeEcSOD, OelAP, OeFas-ligand and Cathepsin B were found to be 2.4,6.5, 3.8 and 3.6-fold over expressed respectively in resistant oysters compared to wild ones (Fig. 6). Cyclophylin was 0.07 fold less expressed in resistant oysters (Fig. 6). No significant difference was found in the expression of Oe-C1q and ferritin between resistant and wild oysters by qRT-PCR (Fig. $6)$.

\section{Discussion}

In the present study, we compared the molecular response of haemocytes from two populations (resistant and wild) to the parasite $B$. ostreae. Molecular responses were studied using suppression subtractive hybridization method (SSH) and real time PCR method. SSH has already been used to better understand host/pathogen interactions at a molecular level in different bivalve species including Crassostrea gigas [19], Crassostrea virginica [20], Saccostrea glomerata [10], O. edulis [21], Ruditapes phillipinarum [22] and Ruditapes decussatus [23]. 
In our study, this method allowed the identification of 1920 ESTs differentially expressed between infected haemocytes from resistant and wild oysters.

A total of 382 ESTs showed similarities with genes available in databases with an E value< 10-4. These ESTs were classified in 8 main categories according to their putative functions predicted by NCBI using GO.

Seven ESTs were selected according to their putative biological function. We have focused on genes involved in detoxification and stress and in cell communication, membrane receptor, and immune system.

The expression pattern of these ESTs was measured in an in vitro infection experiment. Real-time PCR analysis confirmed the differential expression of five out of the seven ESTs (more than one fold difference) while Oe-C1q and Ferritin showed similar expression levels between tested conditions.

A gene presenting homology with $\mathrm{C} 1 \mathrm{q}$ was previously identified in clam species like Mercenaria mercenaria, Mytilus galloprovincialis and Ruditapes decussatus [23], [24] and [25]. $\mathrm{C} 1 \mathrm{q}$ is the first subcomponent of the $\mathrm{C} 1$ complex of the classical pathway of complement activation which is crucial for the clearance of pathogens in vertebrates [26] and invertebrates [27]. The C1q gene was significantly up regulated in Mercenaria mercenaria and $R$. decussatus in response to QPX and Perkinsus olseni, respectively [24] and [23] while in our study the expression of this gene was not affected by the status of the oyster resistant or wild Although $\mathrm{C} 1 \mathrm{q}$ gene was identified in S. glomerata resistant population to the parasite $M$. sydneyi, the expression of this gene appeared not modulated in resistant population compared to wild oyster population [10].

Ferritin has been classified as a s tress protein [19] and has also been associated with defence mechanisms because of its role in the regulation of iron availability to infectious agents [28]. Previous studies showed an increase of ferritin expression in invertebrates following exposures to pathogen-associated molecular patterns (PAMPs) or bacterial challenge [19] and [29]. [24] Perrigault et al. have reported an increase of ferritin expression in clams challenged by Quahaog parasite X (QPX) after 28 and 48 days. In our study, we did not observe difference between wild and resistant oysters suggesting that this mechanism is not involve in resistance or susceptibility to $B$. ostreae.

The putative cyclophilin gene was significantly down regulated in infected haemocytes from resistant oysters. On the contrary, cyclophilin was found up-regulated in response to the bacteria Vibrio splendidus 10 hours after inoculation in resistant cupped oyster Crassostrea gigas [30]. Cyclophilin, a peptidylprolyl isomerase is known in mammals to mediate signalling events leading to T-cell activation [31].

A decrease of phagocytosis activity has been observed when comparing activities of hameocytes from $B$. ostreae infected and no infected resistant oysters (morga pers. com.). This apparent phagocytosis inhibition could be related to the down regulation of the putative cyclophilin observed in the present study.

The over expression of OeEcSOD gene in resistant flat oysters might be related to an increased production of cytotoxic components generated during an immune response as shown by [10] Green et al. in S. glomerata. SOD is known to be involved in the regulation of oxidative stress response. [21] Morga et al. have shown that Oe-EcSOD presented a high sequence homology with other bivalve ecSODs, notably Dominin from the eastern oyster, $C$. virginica [20] with Carvortin from the Pacific oyster, C. gigas [32] and with ecSOD from Saccostrea glomerata [10]. The ability of resistant $O$. edulis to generate hydrogen peroxide at a faster rate and higher concentration than wild flat oysters during respiratory burst could explain their better survival to infection with $B$. ostreae. In a previous study, we showed a significant decrease of reactive oxygen species (ROS) production in wild flat oyster haemocytes after an in vitro infection of $O$. edulis haemocytes with live parasites versus haemocytes alone [33]. Moreover a recent study on the relative expression of this gene after an in vitro infection of haemocytes from wild flat oyster with the parasite Bonamia ostreae revealed a down regulation of OeEcSOD after $1 \mathrm{~h}$ of contact [21]. An increased production of 
SOD in resistant oysters may be regarded as an advantage in controlling negative effects of ROS production on host cells.

Three genes involved in apoptosis (programmed cell death) have been found over expressed in resistant oysters in response to the infection with the parasite $B$. ostreae: genes encoding Fas Ligand, an IAP and cathepsin B. Apoptosis is a common physiological process that eliminates unwanted or diseased cells, and it plays important roles in embryogenesis, homeostasis, metamorphosis and immunity [34] and [35]. The mammalian extrinsic apoptosis pathway is regulated by various genes and factors, including Fas (APO-1 or CD95), Fas ligand (CD95 ligand), tumour necrosis factor (TNF) and related apoptosis-inducing ligand (Apo2L/TRAIL). It is well known that the Fas and Fas ligand (FasL) system plays a central role in apoptosis [35]. Fas is a type I transmembrane glycoprotein that mediates apoptosis and its biological ligand (Fas ligand) induces apoptosis through the binding to Fas [36]. Phylogenic tree analysis of OeFas ligand has shown closest affinity with its homologous in abalone Haliotis discus hannai.

The over expression of the OeFas ligand in infected haemocytes from resistant oysters suggested that the product of this gene is involved in the immune response against the parasite $B$. ostreae.

Inhibitors of apoptosis proteins (IAPs) are a conserved group of proteins that regulate apoptosis in both vertebrates and invertebrates. Since the first discovery of an IAP gene in a baculovirus [37], numerous cellular IAP homologues have been identified [38] The hallmark of an IAP protein is the presence of one to three copies of a zinc-binding baculoviral IAP repeat (BIR) domain. These BIR domains are essential for the anti-apoptotic properties of the IAPs and directly bind to the caspases in order to inhibit them [39] and [40]. The structure of the OeIAP is more similar to the ML-IAP (livin) from human [41] and [42] but the multiple alignment of the BIR domain from OeIAP with BIR domains from other species showed a high identity with the BIR3 domain from Penaeus monodon.

Cathepsins have often been considered as intracellular proteases capable of mediating caspase-independent cell death [43]. Cathepsins have recently been shown to be associated with cell death regulation [44] and [45]. The over expression of the cathepsin B in resistant infected haemocytes leave suspect an implication of this gene in the apoptosis pathway according the previous results notably the over expression of the OeFas-ligand and the OelAP.

All these results suggest that apopotosis plays a key role in the resistance of flat oysters to bonamiosis. Both the parasite and the host might influence this mechanism. By inducing the expression of the anti-apoptotic gene OelAP, B. ostreae seems to inhibit apoptosis in order to survive inside the haemocytes. As for the host, our results seem to indicate that resistant oysters eliminate or limit the development of the parasite by inducing apoptosis. This hypothesis is supported by the over expression of Oe-Fas-ligand observed in resistant oysters versus wild oysters. The manipulation of the host apoptosis by intracellular parasites is currently described in vertebrate and invertebrate hosts [39]. Mammalian intracellular parasites such as Toxoplama gondii, Trypanosoma cruzii, Plasmodium sp., Cryptosporidium parvum are able to trafficking the apoptosis, [46]. Macrophages and T cells infected by the parasite Toxoplasma gondii are able to induce apoptosis by the Fas ligand. However, an inhibition of the apoptosis has also been reported in the macrophage and different cell lines by the up regulation of the anti-apototic homologue such as Bcl-2 [47]. In invertebrates, apopotosis seems to play also a major role in the response to pathogens like in the oyster $C$. virginica against Perkinsus marinus [48] or in the clam R. decussatus against $P$. olseni [23]. A large number of genes involved in apoptosis has recently been identified in $C$. gigas and was found overexpressed in the context of an infection with Vibrio anguillarum [49].

Our study is the first one investigating resistance of a marine bivalve to an infection with an obligate intracellular parasite. It has not only generated new data concerning the flat oyster genome but has also contributed to a better understanding of the molecular basis involved in the resistance to $B$. ostreae infection. Two mechanisms including apoptosis (cathepsin $B$, 
OeFas-ligand and OeIAP) and oxidative detoxification (Oe-EcSOD) appear involved in the resistance to the parasitosis. Further functional studies are now required to better characterized how these mechanisms allow the host to resist to $B$. ostreae.

\section{Acknowledgement}

The Région of Poitou Charentes supported in part this research. The authors thank Raphael Brizard for technical assistance for the maintenance of oysters in IFREMER La Tremblade quarantine facilities. Sylvie Lapègue and Serges Heurtebise are aknowledged for having supplied resistant flat oysters.

\section{References}

[1] Comps M, Tige G, Grizel H. Etude ultrastructurale d'un protiste parasite de l'huître Ostrea edulis (L.). C. R. Acad Science Paris 1980 ; 290 : 383-385.

[2] Pichot Y, Comps M, Tige G, Grizel H, Rabouin MA. Research on Bonamia ostreae gen. n., sp. n., a new parasite of the flat oyster Ostrea edulis (L.). Rev. Trav. Inst. Pêches Marit 1979; 43: 131-140.

[3] Cavalier-Smith T, \& Chao EE. Phylogeny and classification of phylum Cercozoa (Protozoa). Protist 2003; 143: 341-358.

[4] Montes J, Anadon R, Azevedo C. A possible life cycle for Bonamia ostreae on the basis of electron microscopy studies. J. Invertebr. Pathol. 1994; 63: 1-6.

[5] Cheng TC. Bivalves. In: N. A. Ratcliffe and A. F. Rowley, (Eds), Invertebrate Blood Cells. Academic Press. London, 1981, pp. 233-299.

[6] Culloty SC, Cronin MA, Mulcahy MF. Potential resistance of a number of populations of the oyster Ostrea edulis to the parasite Bonamia ostreae. Aquaculture 2004; 237: 41-58.

[7] Lapègue S, Bédier E, Goyard E, Dégremont L, Baud J-P, Gérard et al. Apport d'un programme de génétique à une filière de production aquacole: l'exemple de l'ostréiculture, In: Trente ans de crevetticulture en Nouvelle- Calédonie. Actes Colloq. IFREMER 2004 ; 38 : 113-121.

[8] Naciri-Graven Y, Martin A-G, Baud J-P, Renault T, Gérard A. Selecting the flat oyster Ostrea edulis (L.) for survival when infected with the parasite Bonamia ostreae. J. Exp. Mar. Biol. Ecol. 1998; 224: $91-107$.

[9] Launey S, Barre M, Gerard A, Naciri-Graven Y. Population bottleneck and effective size in Bonamia ostreae-resistant populations of Ostrea edulis as inferred by microsatellite markers, Genet Res. 2001; 78: 259-70.

[10] Green TJ, Tom J, Dixon TJ, Devic E, Adlard RD, Barnes AC. Differential expression of genes encoding anti-oxidant enzymes in Sydney rock oysters, Saccostrea glomerata (Gould) selected for disease resistance. Fish Shellfish Immunol. 2009; 26: 799-810.

[11] Mialhe E, Bachere E, Chagot D, Grizel H. Isolation and purification of the protozoan Bonamia ostreae (Pichot et al. 1980), a parasite affecting the flat oyster Ostrea edulis (L.). Aquaculture 1988; 71: 293-299.

[12] Diatchenko L, Lau YF, Campbell AP, Chenchik A, Moqadam F, Huang B et al. Suppression subtractive hybridization: a method for generating differentially regulated or tissue-specific cDNA probes and libraries. Proc. Natl. Acad. Sci. U S A 1996; 12: 6025-6030. 
[13] Thompson JD, Gibson TJ, Plewniak F, Jeanmougin F, Higgins DG. The Clustal X windows interface: flexible strategies for multiple sequence alignment aided by quality tools. Nucleic Acids Res. 1997; 24: 4876-4882.

[14] Tamura K, Dudley J, Nei M, Kumar S. MEGA4: Molecular Evolutionary Genetics Analysis (MEGA) software version 4.0. Molecular Biology and Evolution 2007; 24: 1596-1599.

[15] Saitou N, \& Nei M. The neighbor-joining method: A new method for reconstructing phylogenetic trees. Molecular Biology and Evolution 1987; 4: 406-425.

[16] Pfall MW. A new mathematical model for relative quantification in real-time RT-PCR. Nucleic Acid Res. 2001; 29: 2002-2007.

[17] Morga B, Arzul I, Faury N, Renault T. Identification of genes from flat oyster Ostrea edulis as suitable housekeeping genes for quantitative real time PCR. Fish Shellfish Immunol. 2010; 29: 937945.

[18] QL,

[19] Gueguen Y, Cadoret J-P, Flament D, Barreau-Roumiguiere C, Girardot AL, Garnier J,et al. Immune gene di scovery by expressed sequence tags generated from hemocytes of the bacteriachallenged oyster, Crassostrea gigas. Gene 2003; 303: 139-145.

[20] Tanguy A, Guo X, \& Ford SE. Discovery of genes expressed in response to Perkinsus marinus challenge in Eastern (Crassostrea virginica) and Pacific (Crassostrea gigas) oysters. Gene 2004; 338: 121-131.

[21] Morga B, Arzul I, Faury N, Segarra A, Chollet B, Renault T. Molecular responses of Ostrea edulis haemocytes to an in vitro infection with Bonamia ostreae. Dev Comp Immunol. 2011; 35: 323-33.

[22] Kang KS, Kim YM, Park KI, Kim Cho S, Choi KS, \& Cho M. Analysis of EST and I ectin expressions in haemocytes of Manila clams (Ruditapes philippinarum) (Bivalvia: Mollusca) infected with Perkinsus olseni. Dev. Comp. Immunol. 2006; 30: 1119-1131.

[23] Prado-Alvarez M, Gestal C, Novoa B, Figueras A. Differentially expressed genes of the carpet shell clam Ruditapes decussatus against Perkinsus olseni. Fish Shellfish Immunol. 2009; 26: 72-83.

[24] Perrigault M, Tanguy A, Allam B. Identification and expression of differentially expressed genes in the hard clam, Mercenaria mercenaria, in response to quahog par asite unknown (QPX). BMC Genomics 2009; 10: 377-387.

[25] Gerdol M, Manfrin C, De M oro G, Figueras A, Novoa B, Venier P, et al. The C1q do main containing proteins of the Mediterranean mussel Mytilus galloprovincialis: a widespread and diverse family of immune-related molecules. Dev. Comp. Immunol. 2011; 35: 635-643.

[26] Kishore U, \& Reid KBM. C1q: structure, function, and receptors, Immunopharmacology. 2001; 49: 159-170.

[27] Zhang H, Song LS, Li CH, Zhao JM, Wang H, Qiu U, et al. A novel C1q-domain-containing protein from Zhikong scallop Chlamys farreri with lipopolysaccharide binding activity. Fish Shellfish Immunol. 2008; 25: 281-289.

[28] Ong DST, Ho JZS, Ho B, Ding JL. Iron-withholding strategy in innate immunity. Immunobiology 2008; 211: 295-314.

[29] Beck G, Ellis TW, Habicht GS, Schluter SF, Marchalonis JJ. Evolution of the acute phase response: iron release by echinoderm (Asterias forbesi) coelomocytes, and cloning of an echinoderm ferritin molecule. Dev. Comp. Immunol. 2002; 26: 11-26. 
[30] Huvet A, Herpin A, Degremont L, Labreuche Y, Samain J-F, Cunningham C. The identification of genes from the oyster Crassostrea gigas that are differentially expressed in progeny exhibiting opposed susceptibility to summer mortality. Gene 2004; 343: 211-220.

[32] Scotti PD, Dearing SC, Greenwood DR. Characterisation of cavortin, the major haemolymph protein of the Pacific oyster (Crassostrea gigas). New Zeal J Mar Freshwater Res. 2007; 41: 91-101.

[33] Morga B, Arzul I, Chollet B, Renault T. Infection with the protozoan parasite Bonamia ostreae modifies in vitro haemocyte activities of flat oyster Ostrea edulis. Fish Shellfish Immunol. 2009; 26: 836-842.

[34] Vaux DL, \& Korsmeyer SJ. Cell death in development. Cell 1990; 96: 245-254.

[36] Curtin JF, \& Cotter TG. Live and let die: regulatory mechanisms in Fas-mediated apoptosis. Cell Signal. 2003; 15: 983-992.

[38] Salvesen GS, \& Duckett CS. IAP proteins: blocking the road to death's door. Nat. Rev. Mol. Cell. Biol. 2003; 3: 401-410.

[39] Deveraux QL, Takahashi R, Salvesen GS, Reed JC. X-linked IAP is a direct inhibitor of cell-death proteases. Nature 1997; 388: 300-304.

[40] Roy N, Deveraux QL, Takahashi R, Salvesen GS, Reed JC. The c-IAP-1 and c-IAP-2 proteins are direct inhibitors of specific caspases. EMBO J. 1997; 16: 6914-6925.

[41] Kasof GM, \& Gomes BC. Livin, a novel inhibitor of apoptosis protein family member. J. Biol. Chem. 2001; 276: 3238-46.

[42] Vucic D, Deshayes K, Ackerly H, Pisabarro MT, Kadkhodayan S, Dixit VM SMAC negatively regulates the anti-apoptotic activity of melanoma inhibitor of apoptosis (ML-IAP). J. Biol. Chem. 2002; 277: 12275-12279.

[43] Lockshin RA, \& Zakeri Z. Caspase-independent cell death? Oncogene 2004; 23: 2766-2773.

[44] Foghsgaard L, Wissing D, Mauch D, Lademann U, Bastholm L, Boes M, et al. Cathepsin B acts as a dom inant execution protease in tumor cell apoptosis induced by tumor necrosis factor. J. Cell. Biol. 2001; 153: 999-1009.

[45] Heussler VT, Küenzi P, Rottenberg S. Inhibition of apoptosis by intracellular protozoan parasites. Int. J. Parasitol. 2001; 31: 1166-76.

[46] Lüder CG, Gross U, Lopes MF. Intracellular protozoan parasites and apoptosis: diverse strategies to modulate parasite-host interactions. Trends Parasitol. 2001; 17: 480-486.

[47] Orlofsky A, Somogyi RD, Weiss LM, Prystowsky MB. The murine antiapoptotic protein A1 is induced in inflammatory macrophages and constitutively expressed in neutrophils. J. Immunol. 1999; 163: 412-419.

[48] Hughes FM, Foster B, Grewal S, Sokolova IM. Apoptosis as a ho st defense mechanism in Crassostrea virginica and its modulation by Perkinsus marinus. Fish Shellfish Immunol. 2010; 29: 247257.

[49] Zhang L, Li L, Zhang G. Gene discovery, comparative analysis and expression profile reveal the complexity of the Crassostrea gigas apoptosis system, Dev Comp Immunol. 2011; 35: 603-610. 


\section{Figure legends}

Figure 1 Functional classification of the sequences identified in both libraries (ESTs). Genes were clustered into $8 \mathrm{c}$ ategories according to their putative biological function (A Forward bank and $B$ reverse bank).

Figure 2 Complete ORF nucleotide and deduced amino acid sequences of the flat oyster OeFas-ligand. ORF contains a peptid signal (boxed in black), a transmembrane domain (uderlined in black) and a TNF domain (dotted in black). N-glycosylation sites were surrounded.

Figure 3 Neighbour-joining tree showing phylogenetic analysis of Fas ligand, TNF alpha and lymphotoxin sequences from various species (Fas ligand: Homo sapiens sapiens NP000630, Mus musculus NP034307, Rattus norvegicus NP037040, Macaca mulatta AB035139.1, Sus scorfa AB069764.1, Haliotis discus discus ASJ12607; TNF alpha: Homo sapiens sapiens M10988.1, Mus musculus U68414.1, Rattus norvegicus X66539.1, Sus scorfa X57321.1, Bos Taurus NP776391, Xenopus tropicalis AM041993.1, Oreochromis niloticus AY428948.1, Paralichtys olivaetus AB040448.1, Ictalurus punctatus AJ417565.2, Salmo salar NP001117061; Lymphotoxin alpha: Homo sapiens sapiens X01393.1, Rattus norvegicus NP542947, Sus scorfa NP999618, Bos Taurus Z14137.1, Xenopus tropicalis AM041994.1). The tree is based on 1000 bootstrap replications. The scale for branch length $(0.1$ substitutions/site) is shown below the tree.

Figure 4 Complete ORF nucleotide and deduced amino acid sequences of the flat oyster OeIAP. ORF contains a BIR domain (uderlined in black) and a RING finger domain (dotted in black). Signature amino acids were boxed in red. N-glycosylation sites were surrounded.

Figure 5 Multiple sequence alignments of the BIR and RING domains of OeIAP with the corresponding domains of other IAP family members : Penaeus monodon IAP (PmIAP ABO38431.1), Drosophila melanogaster IAPs (DIAP1 Q24306.2) and (DIAP2 AAF58095.1) and Homo sapiens sapiens ML-IAP (livin NP_647478.1). Identical residues are indicated in black and similar residues are indicated in grey.

Figure 6 Relative expression by quantitative PCR of selected transcripts from SSH libraries (OelAP, OeFas-ligand, OeEc-SOD, OeC1q, ferritin, cathepsin B and cyclophillin). Expression levels were normalized to EF1-a and presented as relative expression to controls (mean \pm $\mathrm{SD}, \mathrm{n}=2$ ). * Indicates significant differences of gene expression compared to controls. 
A
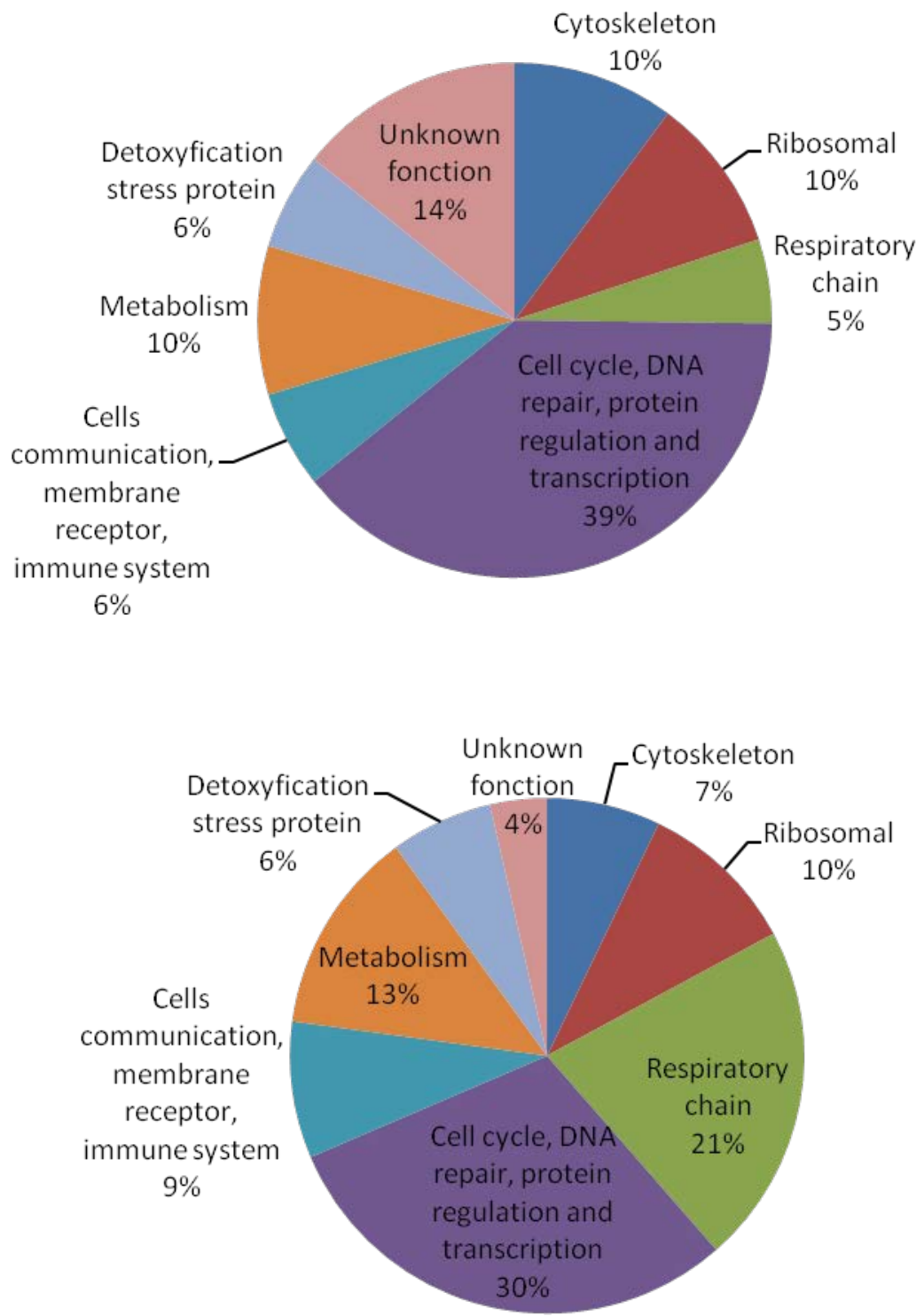

Figure 1 


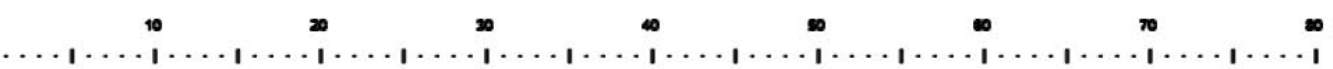

TA CGCGGGA GA GA TCAAAA CA CA T TCA GGA TGAGTGCTCCA TCGAGTCGAAA TTGCAAGTGCTTCA TGA TA TTTTCCTGT 80

M S A P S S R N C K C F M I F S C

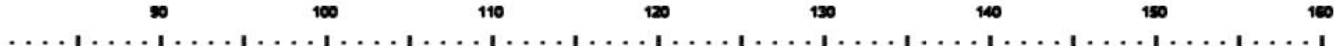

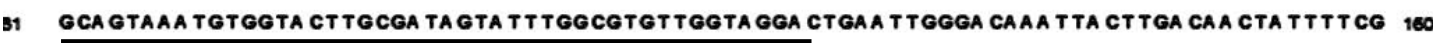

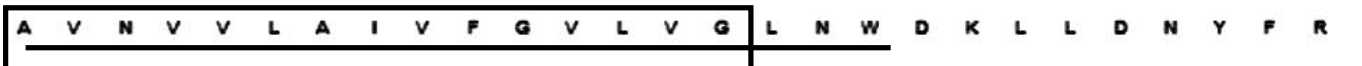

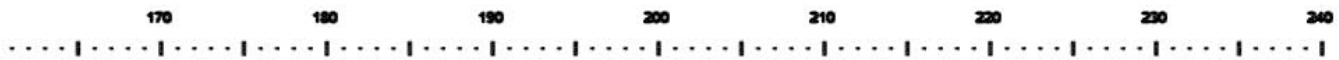

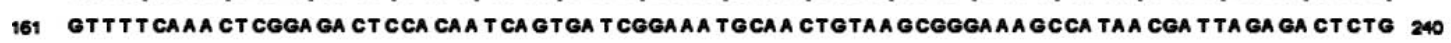

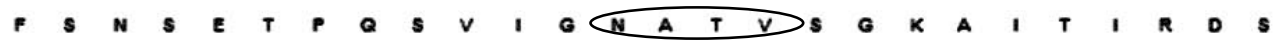

200
$\cdots$

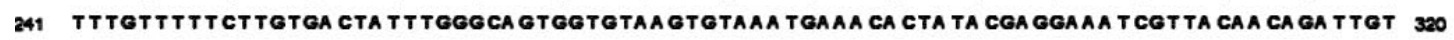

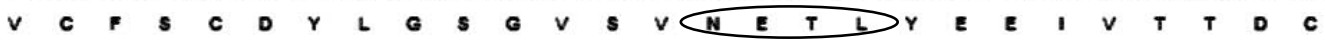

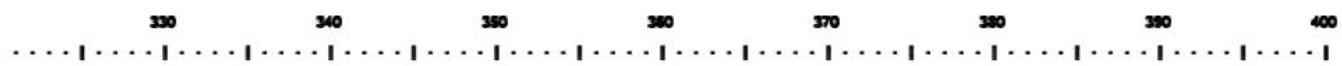

321 AAA CA CAAA CTGTGCTGCA TAAAAGA CAAAGTGA TCCA TGATTTTGTGA TAGCGA CTCAAAATGAAAATAA CGAAAATGA 400

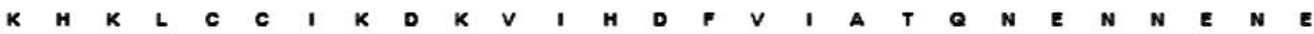

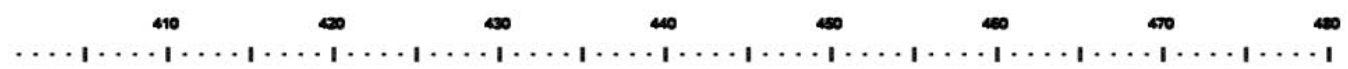

401 AAA CA GTTCA TCAA TTA GGGA TTCCTT CGCCTGGTGGA GAAA CA GGGCTAA CT CA GCCCA TTTCTA TCTGGA CCGGGAA 480

N S S S I R D

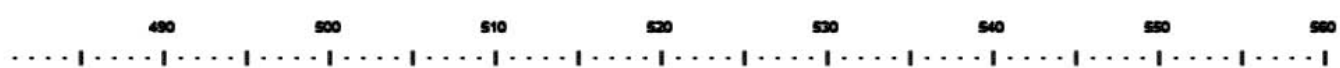

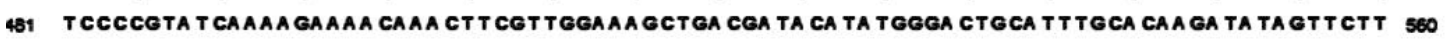

I P $V$ S K N K L

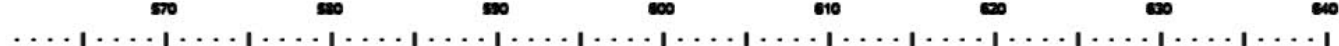

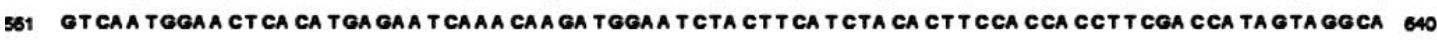

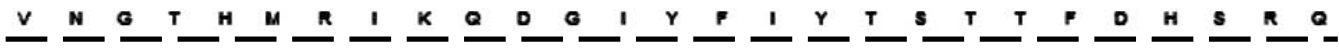

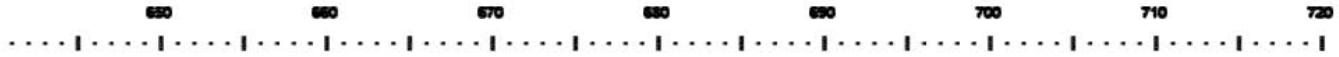

BA1 GGA CA CGgTGGAAA CCA TCTA TCAAAGT CTGA TCAAGTA CCA CCCTTATTTA CCAAAGA CA GGCGA CGTGGA CCTCGTTT 72O

D T V E T I Y Q S L I K Y H P Y L P K T G D V D L V

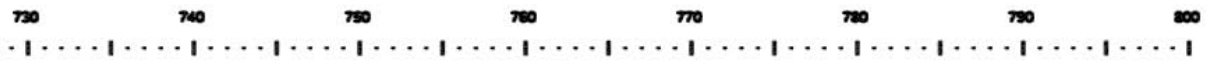

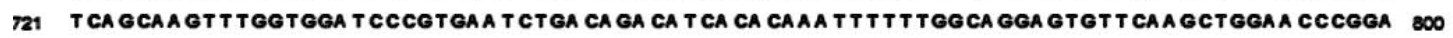

F S K F G G S R E S D R H H T N F L A G V F K L E P G

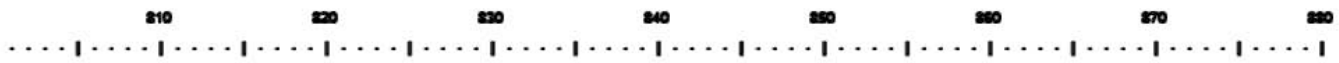

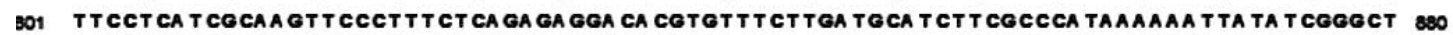

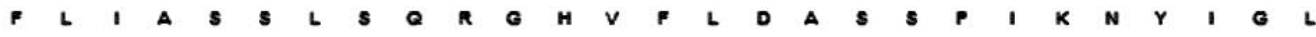

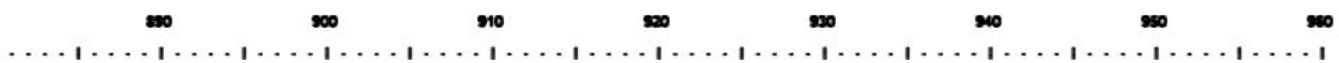

31 A TA TAAGTTA TA GCTA CCA GA TA CAA TAGTTGAAA CTGAAA TGA TTTGA TA CTGAGA GTA CA CTAGCTGTGTAAATGCCA gGO

$Y$ K L : L P D T I V E T E M I

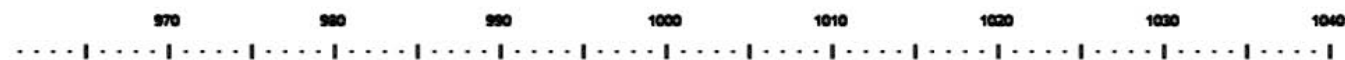

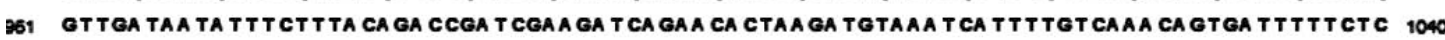

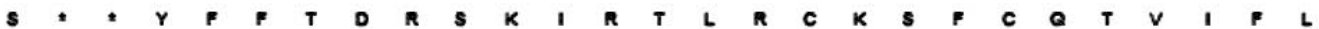

Figure 2 
Figure 3

a

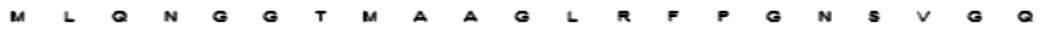

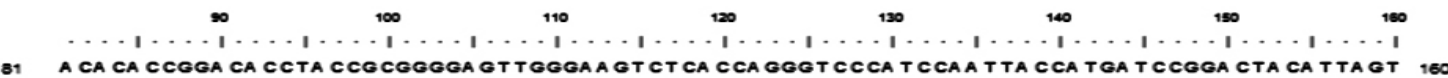

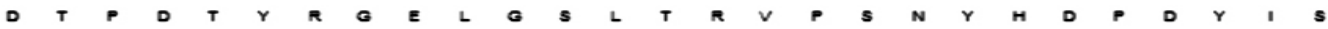

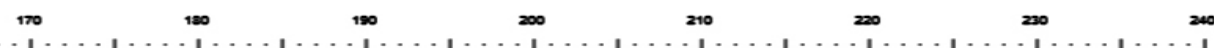

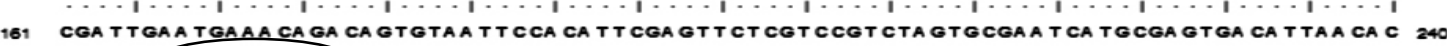

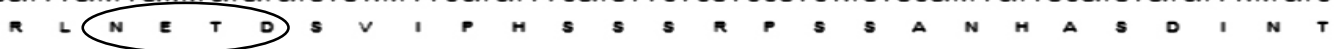

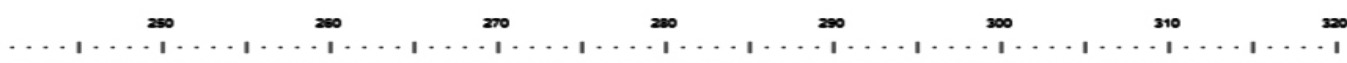

241 TOT CCCGAGA CCCCAA CA CGCGAAATA TCCGGA CTA TT CA CA GA GTGGGAA CGAATTGCCT CGTACAATAA CTGGCCAC 320

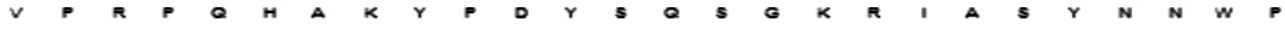

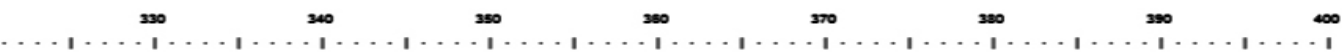

321 CAA CA GCAAAA CA GAA T CCA CA GAATTTGGCCGA TGCTGGTTTTTTTTA TA CA GGT CAA GCGGA CA GTOTCCGGTGCTTT 400

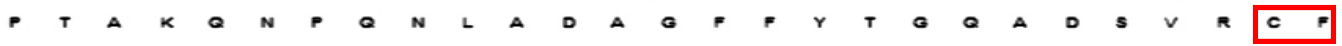

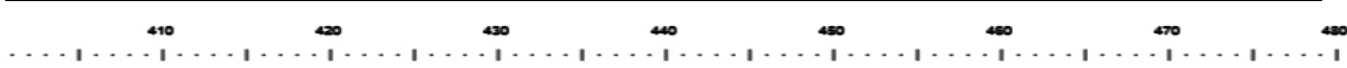

401 A TCTGTGGGA CA GGGCT CA GGAA CTGGGA CCCGGA GGA TGA GCCCTGGGT CGAA CA CGCC CGCTGGGCCCCTGAGTGTTT 490

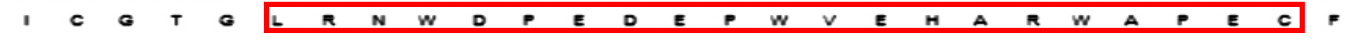

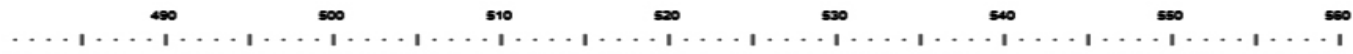

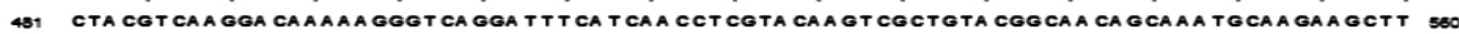

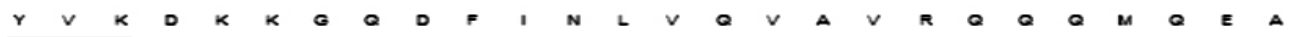

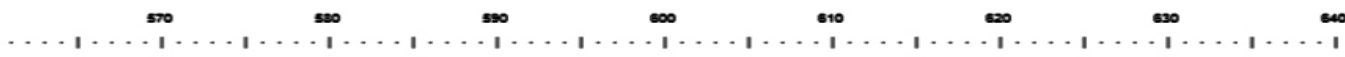

561 TA CAA CA GCA GT CGGA TCCA TGA CGA GGGAGGCTA CA GA TGTTGCTGCGGA CTGTGCA CCCCCTAATCTGGA TAAAGAT GAO

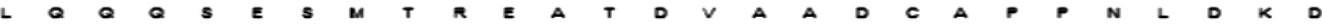

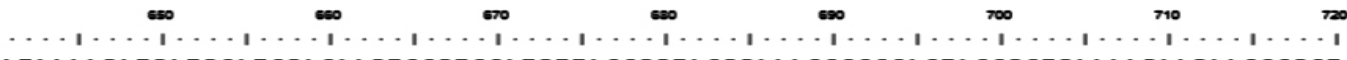
64. A TAAAAGA TGA TGCA TCGA CAAGT CCGT CCATGTTA CCGGTA CGGAAA CCCCCCA CTA CCGCTGAAAAGAAGAA CCCGCT TZO I K D D A S T S P S M L P V R K P P T T

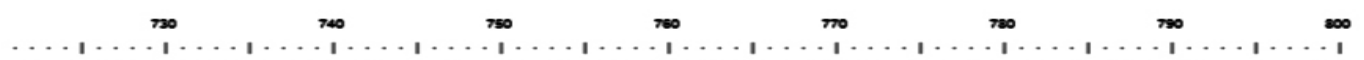

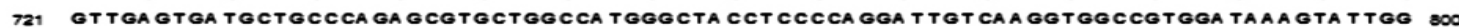

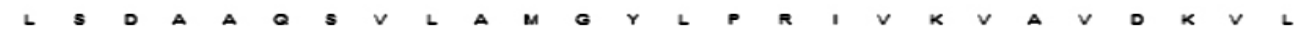

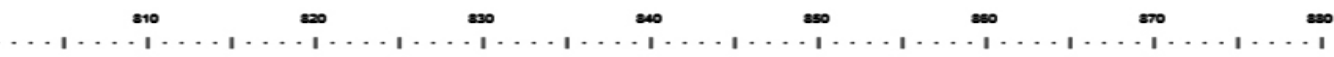

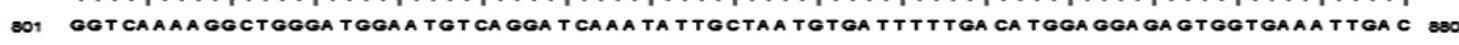

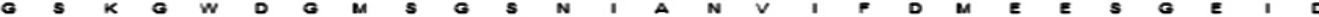

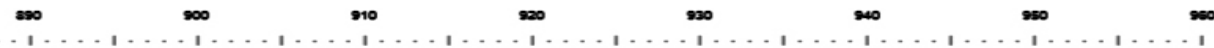

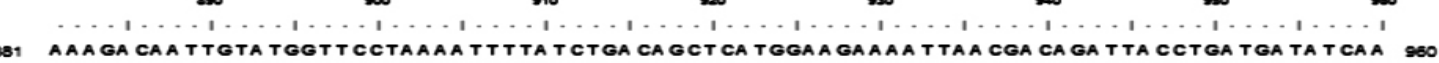

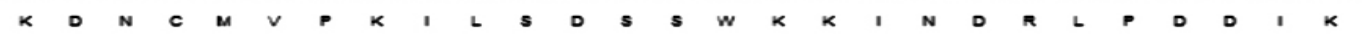

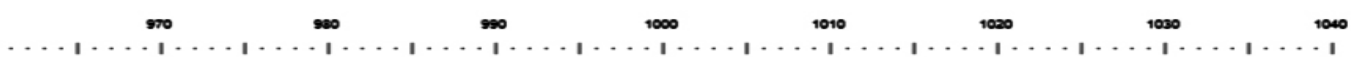

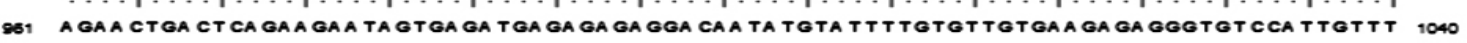

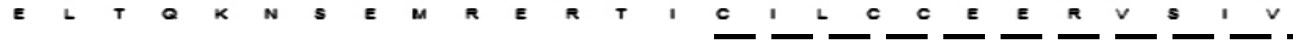

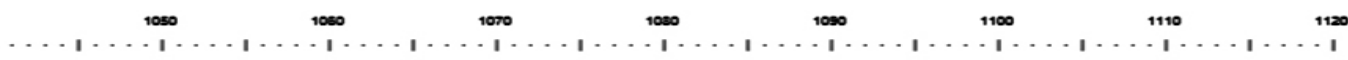
1041 TTTTA CССTGCGGA CA CСTGGTCAGTTGTGCCCAGTGTTCTCCAGCTTTAAAAAA CTGCCCAGTGTGTCGGGA TCCATC 1120

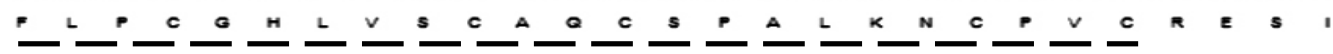

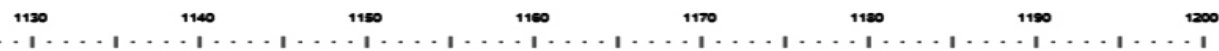
1121 AAA GGGA CGGT CCGAGTGTCTTTTGCA TGAGTTGGTCAAA CAAATTCAAT COCCCAAAAAAA TGCAAA CAAAA CA TA TTA 1200 $K G T$ T $V$ R $S$ F A

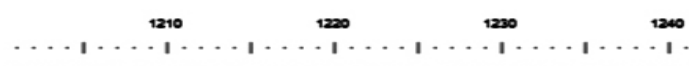
1201 AA CTA TAA CAA CAATAA CAA CAAAAAAAAAAAAAAAAAAAA 124 


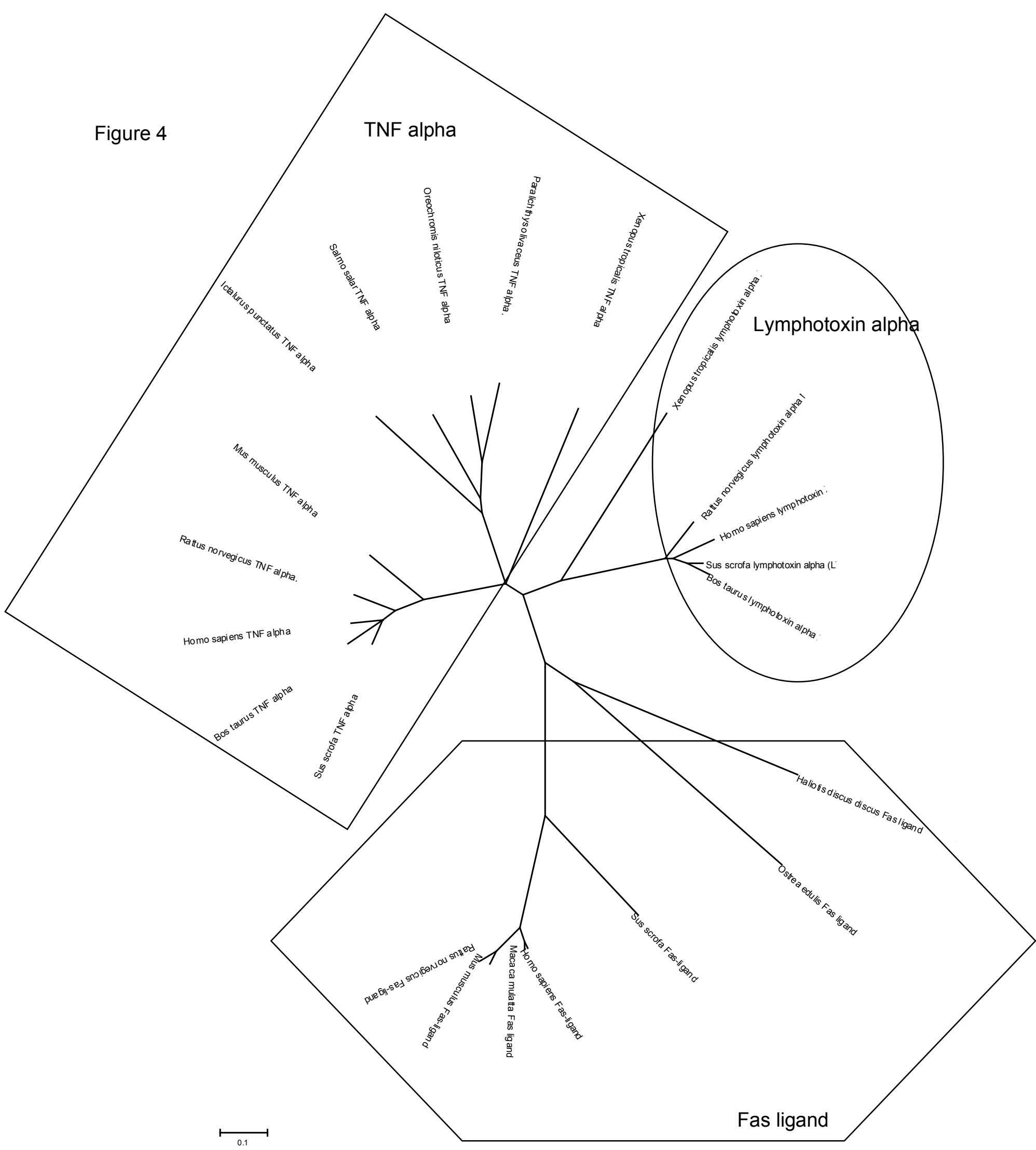




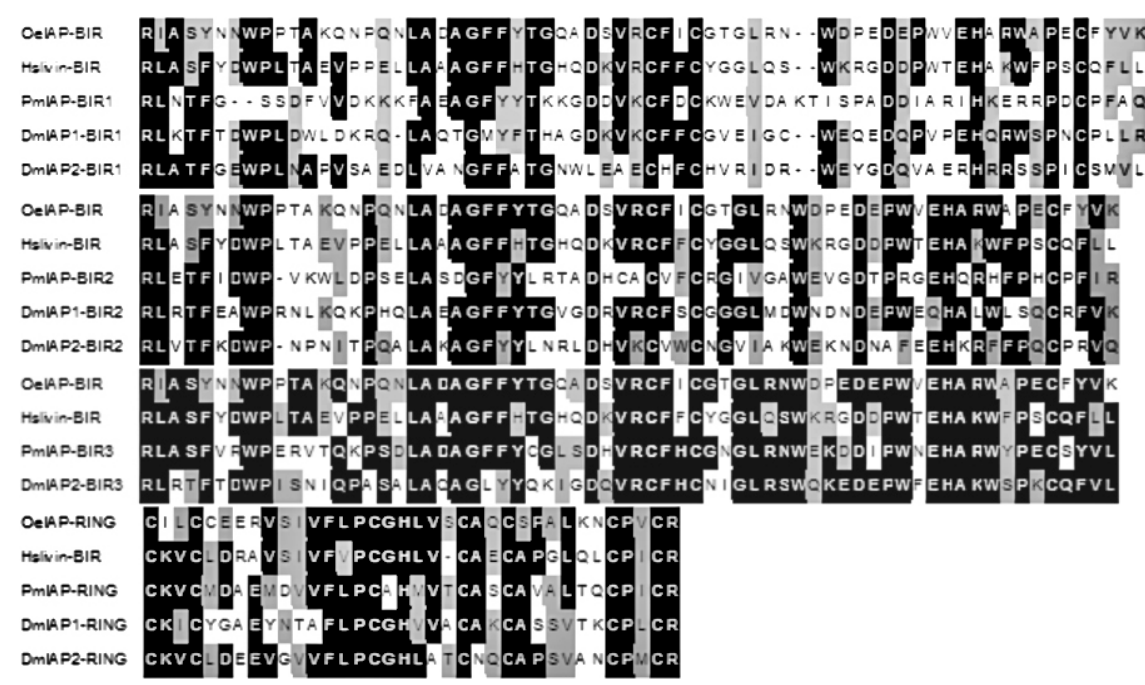

$\begin{array}{ll}51 \% & 70 \% \\ 25 \% & 48 \% \\ 36 \% & 66 \% \\ 30 \% & 48 \% \\ & \\ & \\ 51 \% & 70 \% \\ 31 \% & 50 \% \\ 53 \% & 74 \% \\ 34 \% & 61 \% \\ & \\ & \\ 51 \% & 70 \% \\ 62 \% & 72 \% \\ 46 \% & 65 \% \\ & \\ & \\ 61 \% & 80 \% \\ 50 \% & 75 \% \\ 44 \% & 69 \% \\ 58 \% & 80 \%\end{array}$

Figure 5

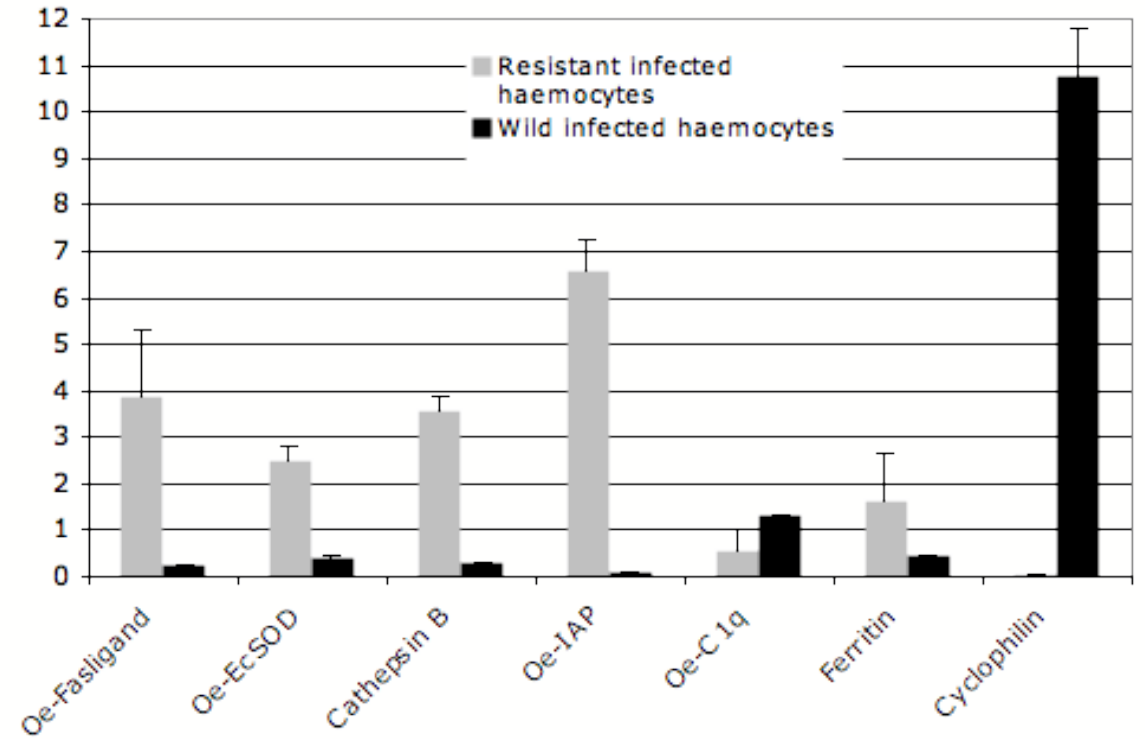

Figure 6 
Tables

\begin{tabular}{|c|c|c|c|}
\hline Name & Oligonucleotide sequence (5'-3') & $\begin{array}{l}\text { Concentration } \\
\text { of Forward } \\
\text { primer }(\mu \mathrm{M})\end{array}$ & $\begin{array}{l}\text { Concentration } \\
\text { of Reverse } \\
\text { primer }(\mu \mathrm{M})\end{array}$ \\
\hline OelAP & $\begin{array}{l}\text { Forward: CTACCTCCCCAGGATTGTCA } \\
\text { Reverse: CACCACTCTCCTCCATGTCA }\end{array}$ & 年 & r \\
\hline OeFas & $\begin{array}{l}\text { Forward: TTTGGGCAGTGGTGTAAGTG } \\
\text { Reverse: TAGCCCTGTTTCTCCACCAG }\end{array}$ & 1.5 & 3 \\
\hline Cathep & $\begin{array}{l}\text { Forward: CTGCACTGATCTGGGACTCA } \\
\text { Reverse: ATTACYGGCTGGTGGCAAAC }\end{array}$ & 3 & 3 \\
\hline OeEc-SOD & $\begin{array}{l}\text { Forward:GAGGAGGAAGAGGACCATCC } \\
\text { Reverse: ATTTTCCTCCGCTTTGTGTG }\end{array}$ & 2,5 & 2,5 \\
\hline Oefer & $\begin{array}{l}\text { Forward: GATGTGATCGGACACCTCCT } \\
\text { Reverse: TCACAAAGTTGCAGGCAGTC }\end{array}$ & 3 & 3 \\
\hline OeC1q & $\begin{array}{l}\text { Forward: CAGTCCCTCAGAGCCTGTTC } \\
\text { Reverse: ACAGGTATACGCCGGTTTTG }\end{array}$ & 3 & 3 \\
\hline Oepepti & $\begin{array}{l}\text { Forward: ATGAGCCAGGTCATCAAAGG } \\
\text { Reverse: GGCCTAGGAGTTCCACATCA }\end{array}$ & 3 & 3 \\
\hline ElongPCRQ5m & $\begin{array}{l}\text { Forward:GTCGCTCACAGAAGCTGTACC } \\
\text { Reverse: CCAGGGTGGTTCAAGATGAT }\end{array}$ & 3 & 3 \\
\hline TOPO & $\begin{array}{l}\text { Forward: GACCATGATTACGCCAAGC } \\
\text { Reverse: CCCAGTCACGACGTTG }\end{array}$ & & \\
\hline
\end{tabular}

Table 1: Combinations of primers used in quantitative PCR assays and for amplification of plasmid TOPO TA Cloning (Invitrogen).

\begin{tabular}{|l|l|}
\hline Total clones sequenced & 1920 \\
\hline Sequences analysed & 1831 \\
\hline Total of sequences with significant match & 382 \\
\hline Contigs & 333 \\
\hline Singletons & 606 \\
\hline Redundancy & $48 \%$ \\
\hline Average size number pb & 450 \\
\hline
\end{tabular}

Table 2: General characteristics of the subtracted library and cDNA sequences from Ostrea edulis haemocyte. 


\section{Detoxification and stress protein}

MAP-kinase activating death domain

\section{Ferritin}

Universal stress protein family

HSP70

dominin precursor

heat shock protein $70 \mathrm{~B}$
Metallothionein

heat shock protein 90 putative

HSP90 family member

Xenopus tropicalis

Crassostrea ariakensis

Crassostrea ariakensis

Nematostella vectensis

Ostrea edulis

Albugo laibachii Nc14

Albugo laibachii Nc14

Albugo laibachii Nc14

Albugo laibachii Nc14

Albugo laibachii Nc14

Thalassiosira pseudonana

Acanthamoeba culbertsoni

Crassostrea virginica

Crassostrea gigas

$\begin{array}{lll}4 \mathrm{e}-04 & 397 & \text { NP_001072717 } \\ 4 \mathrm{e}-04 & 397 & \text { NP_001072717 } \\ 2 \mathrm{e}-31 & 360 & \text { ABE99842 } \\ 4 \mathrm{e}-42 & 516 & \text { ABE99842 } \\ 4 \mathrm{e}-05 & 384 & \text { XP_001641771 } \\ 4 \mathrm{e}-25 & 302 & \text { CAC83770 } \\ 1 \mathrm{e}-39 & 419 & \text { CCA24455 } \\ 2 \mathrm{e}-46 & 419 & \text { CCA24455 } \\ 1 \mathrm{e}-48 & 482 & \text { CCA24455 } \\ 4 \mathrm{e}-52 & 518 & \text { CCA24455 } \\ 2 \mathrm{e}-39 & 416 & \text { CCA24455 } \\ 1 \mathrm{e}-52 & 633 & \text { XP_002291118 } \\ 6 \mathrm{e}-21 & 216 & \text { AAU94664 } \\ 1 \mathrm{e}-39 & 589 & \text { BAF30874 } \\ 1 \mathrm{e}-53 & 441 & \text { BAJ83619 }\end{array}$

Cell communication, receptor and immune system protein
Saccoglossus kowalevskii

Glossina morsitans morsitans

Crassostrea gigas

Brugia malayi

Brugia malayi

Canis familiaris

Crassostrea ariakensis

Canis lupus familiaris

Metarhizium anisopliae

Theileria parva strain Muguga

Maconellicoccus hirsutus

Maconellicoccus hirsutus

Pinctada fucata

Haliotis discus discus

Rattus norvegicus

$\begin{array}{lll}2 e-08 & 420 & \text { XP_002731444 } \\ 4 e-13 & 363 & \text { ADD19534 } \\ 5 e-31 & 540 & \text { AEB54800 } \\ 3 e-09 & 176 & \text { XP_001900327 } \\ 3 e-09 & 176 & \text { XP_001900327 } \\ 3 e-07 & 525 & \text { XP_539160 } \\ 5 e-56 & 542 & \text { ABQ59345 } \\ 0.031 & 332 & \text { AAG10039 } \\ 1 e-39 & 552 & \text { EFZ01921 } \\ 2 e-36 & 482 & \text { XP_765771 } \\ 1 e-49 & 420 & \text { ABM55516 } \\ 6 e-51 & 404 & \text { ABM55516 } \\ 1 e-30 & 411 & \text { ADX32985 } \\ 6 e-06 & 482 & \text { ACJ12607 } \\ 2 e-15 & 298 & \text { EDL82568 }\end{array}$

$2 \mathrm{e}-15$

298

EDL82568

Fas ligand-like protein

cystathionase

Table 3A: Identified SSH up-regulated clones in categories 1 and 2 in Bonamia ostreae infected haemocytes from resistant flat oysters with significant database match (Forward bank). 


\section{Detoxification and stress protein}

\begin{tabular}{|c|c|c|c|c|}
\hline Stress-associated endoplasmic reticulum protein 1 & Salmo salar & $1 \mathrm{e}-20$ & 331 & ACM08529 \\
\hline Similar to cytochrome P450, family 2 , subfamily j, polypeptide 6 & Ciona intestinalis & $2 e-11$ & 328 & XP_002124100 \\
\hline \multirow[t]{2}{*}{ Ferritin GF2 } & Crassostrea gigas & $1 e-38$ & 472 & AAP83794 \\
\hline & Crassostrea gigas & $5 e-15$ & 284 & AAP83794 \\
\hline Heat shock protein 90 & Crassostrea hongkongensis & $2 e-89$ & 532 & ADL59936 \\
\hline Similar to MEK5alpha-1 & Strongylocentrotus purpuratus & $2-16$ & 326 & XP_786275 \\
\hline Heat shock protein 70 & Crassostrea virginica & $1 e-42$ & 295 & CAB89802 \\
\hline Universal stress protein family & Nematostella vectensis & $4 e-04$ & 266 & XP_001626758 \\
\hline Metallothionein & Ostrea edulis & $1 \mathrm{e}-08$ & 207 & CAC83770 \\
\hline
\end{tabular}

Cell communication, receptor and immune system protein

\begin{tabular}{|c|c|c|c|c|}
\hline cathepsin B sequence & Pinctada fucata & $9 e-80$ & 511 & ADX32985 \\
\hline \multirow[t]{2}{*}{ Hypothetical protein isoform 1 containing immunoglobulin domain } & Strongylocentrotus purpuratus & $2 e-11$ & 301 & XP_782924 \\
\hline & Strongylocentrotus purpuratus & $4 e-12$ & 319 & XP_782924 \\
\hline \multirow[t]{2}{*}{ Peptidyl-prolyl cis-trans isomerase (cyclophilin) } & Haliotis discus discus & $8 e-29$ & 279 & ABO26659 \\
\hline & Haliotis discus discus & $4 e-09$ & 244 & ABO26659 \\
\hline Cystatin B-like protein & Crassostrea gigas & $3 e-38$ & 439 & ADI33157 \\
\hline Peptidyl-prolyl cis-trans isomerase B & Danio rerio & $4 e-09$ & 244 & NP_998184 \\
\hline Very low-density lipoprotein receptor & Culex quinquefasciatus & $4 e-04$ & 592 & XP_001845800 \\
\hline Prostaglandin E2 receptor EP4 subtype-like & Pongo abelii & $3 e-05$ & 148 & XP_002815561 \\
\hline PREDICTED: similar to Neurogenic locus Notch protein precursor & Ciona intestinalis & $4 e-07$ & 359 & XP_002123017 \\
\hline Putative $\mathrm{C} 1 \mathrm{q}$ domain containing protein $\mathrm{MgC1q78}$ & Mytilus galloprovincialis & $4 \mathrm{e}-04$ & 344 & $\mathrm{CB} \overline{\mathrm{X}} 41727$ \\
\hline Senescence-associated protein & Brugia malayi & $7 e-44$ & 453 & XP_001900327 \\
\hline
\end{tabular}

Table 3B: Identified SSH up-regulated clones in categories 1 and 2 in Bonamia ostreae infected haemocytes from wild flat oysters with significant database match (Reverse bank). 